\title{
Densely Granulated Corticotroph Adenoma
}

National Cancer Institute

\section{Source}

National Cancer Institute. Densely Granulated Corticotroph Adenoma. NCI Thesaurus.

Code C154339.

A corticotroph adenoma composed of basophilic PAS-positive cells that are diffusely and strongly positive for ACT H, consistent with the abundance of secretory granules seen at the ultrastructural level. (WHO 2017) 